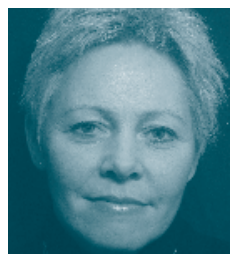

May Aasebø Hauken, cand. polit./instituttleder Betanien diakonale høyskole, Institutt for videre- og etterutdanning

Dette er andre del av to artikler om prosjektarbeid skrevet av samme forfatter. Den første: «Hva er et godt prosjektarbeid?» ble trykket i Sykepleien nr. 172009. Ligger også på sykepleien.no

www.sykepleien.no

Les mer og finn litteraturhenvisninger på våre nettsider

Søkeord: > Prosjektarbeid ) Ledelse

> Prosjektarbeid ) Styringsgruppe ) Referansegruppe

\title{
Sykepleier \\ som prosjektleder
}

Mange sykepleiere blir involvert i prosjektledelse i løpet av yrkeskarrieren.

Da er det viktig med grunnleggende kunnskap om prosjektledelse for å lykkes.

$\mathbf{P}$ rosjektledelse er situasjonsbestemt og preget av stadige endringer, og er en meget krevende ledelsesform. En viktig forutsetning for å kunne lede et prosjekt, er at både de som sitter med det formelle lederansvar i prosjektet og de øvrige prosjektdeltakerne har grunnleggende kunnskap om særtrekkene ved prosjektarbeid og prosjektledelse. Prosjektleder har en viktig rolle som integrator og er den som samler trådende mellom alle nivå i prosjektet.

På bakgrunn av min erfaring som prosjektleder, -medarbeider og -veileder har jeg erfart at mange prosjekter er dårlig styrt, noe som blant annet skyldes mangel på grunnleggende kunnskaper om prosjektledelse. Prosjekter krever en annen ledelse enn daglig drift, og styringsbehovet for prosjekter er ofte undervurdert. Hensikten med denne artikkelen er derfor å klargjøre hva prosjektledelse innebærer, særtrekk ved prosjektleders rolle og sentrale elementer i prosjektledelse som planlegging, teambygging, kommunikasjon, målrettet ledelse og oppfølging. Grunnleggende kunnskap om prosjektledelse er viktig enten man sitter i styringsgruppen, er prosjektleder eller prosjektmedarbeider, og kan være avgjørende for om et prosjekt lykkes eller ikke.

\section{Prosjektledelse er situasjonsbestemt}

Et prosjekt kan defineres som «en spesiell, målrettet og avgrenset arbeidsoppgave som krever en samordnet, menneskelig innsats» (1. s. 18). Den faktoren som kanskje klarest skiller prosjektarbeid fra «vanlig» arbeid i organisasjonen, er prosjektets livssyklus (2). Prosjekters livssyklus karakteriseres av ulike faser, det vil si en gruppe av likeartede aktiviteter som må gjennomføres i en bestemt rekkefølge (2). Hva man kaller prosjektfasene varierer i litteraturen $(1$ - 4), men generelt er det vanlig å inndele prosjekter i en planleggingsfase, oppstartsfase, gjennomføringsfase og avslutningsfase. I prosjektets viktige planleggingsfase legges prosjektets strategi knyttet til hensikt, mål, prosjektorganisasjon, fremdriftsplan, budsjett og rapportering. I prosjektets oppstartsfase formes og bemannes organisasjonsstrukturen og prosjektets normer og kultur dannes. Denne fasen benevnes ofte som «forming, storming og norming», noe som godt beskriver fasen og utfordringer knyttet til denne (2). Det meste av arbeidet i prosjektet utføres i gjennomføringsfasen der sentrale oppgaver er oppfølging av fremdrift, økonomi og oppnåelse av delmål og mål (3). Prosjektarbeidet avsluttes i avslutningsfasen, en fase som ofte kan være vanskelig både knyttet til faglige og følelsesrelaterte problemer (2).

Ovenstående viser at prosjektarbeid foregår i ulike situasjoner, gjennom ulike prosjekttyper, ulike faser og med ulike rammebetingelser (1-4). Dette tydeliggjør at prosjektledelse er situasjonsbestemt. Situasjonsbestemt ledelse innebærer forskjellig lederstil og forskjellige ferdigheter både i forhold til medarbeidere og til oppgavene i prosjektets forskjellige faser (1-3). Situasjonsbestemt ledelse stiller ikke bare store krav til prosjektleder, men også til medlemmer av styringsgruppen, prosjektgruppen og referansegruppen ved at alle må kjenne sin egen rolle og ansvarsområde i de enkelte fasene av prosjektet (3).

Siden det typiske for prosjektledelse er at situasjonen stadig forandrer seg, er prosjektledelsen i stor grad preget av endringsledelse $(1,5,6)$. Situasjonsbestemt ledelse er kjent som en krevende ledelsesform, og i større prosjekter hender det at en skifter prosjektledelse ved overgang til nye faser (2).

\section{Prosjektlederrollen}

Styringsgruppen har den formelle ledelsen og avgjørelsesmyndighet i et prosjekt. Prosjektleder har en delegert avgjørelsesmyndighet innen gitte rammer fra styringsgruppen og er den som utfører prosjektledelsen. Prosjektleder, som er hovedansvarlig for prosjektets daglige drift, har derfor en svært sentral lederrolle i alle prosjekt, og valg av prosjektleder bør skje så tidlig som mulig (1).

I prosjektlitteraturen er det skrevet mye om hva god prosjektledelse er og hvilke egenskaper en god prosjektleder bør ha (1-6). Siden prosjektledelse er situasjonsbestemt, innebærer dette at prosjektlederrollen består av flere ulike lederroller integrert i en. Dette stiller krav til egenskaper som tilpasningsdyktighet, fleksibilitet, smidighet, forhandlingsevne samt evne til å skape trygghet og motivasjon (3). Ingen er supermennesker og kan oppfylle alle lederroller samtidig, og derfor omtales ofte prosjektleders viktigste rolle som «integratorrollen» $(1,3)$. Som integrator er prosjektleder den som samordner og skaper helhet i prosjektet, tilrettelegger, gir retning og energi til prosesser og mennesker. Prosjektleder må ha flere fokus samtidig. Bringer et al. (6) har på bakgrunn av integratorrollen, utarbeidet et «prosjektlederkompass». Prosjektlederkompasset har seks hovedretninger, to retninger på tre ulike plan som viser hvilke hovedområder prosjektleder må fokusere på:

> Prosjektets eiere/mottakere og andre interessenter: Prosjektleder må holde kontakt med oppdragsgiver/styringsgruppe; sørge for at styringsgruppen har snakket sammen, at kontrakt og prosjektleders mandat er klargjort, samt klargjøre beslutningssituasjoner ved å legge fram tilstrekkelig beslutningsgrunnlag (3). Det er også viktig at prosjektleder holder kontakt med prosjektets interessenter for 
eksempel kollegaer, ledere og andre som berøres av prosjektet for å markedsføre, bygge tillit og troverdighet rundt prosjektet.

I Prosjektets egen framdrift og forløp, prosjektets livssyklus: Prosjektleder skal følge med fremdriften, sørge for at prosjektet når mål og milepæler. Videre må prosjektleder også være forutseende, den som har overblikk over situasjonen og planlegger driften på en slik måte at målene nås innenfor de gitte ressursrammene $(6,3)$.

, Prosjektdeltakerne og deres prestasjoner: Prosjektleder er leder og må være bevisst på egen rolle, vurdere egen innsats og tilpasse sin lederstil til situasjonen (3). Fokus for prosjektleder skal være på konkrete resultater og kvalitet og ikke kun på aktiviteter. Det er derfor viktig at milepæler og måloppnåelse underveis feires, og at prosjektmedarbeiderne får konstruktive tilbakemeldinger og ros. Prosjektleder er også viktig for etablering og opprettholdes av et støttende og kreativt klima. Dette innebærer både handlinger som er rettet mot oppgaveløsning og resultat, og handlinger som har til hensikt å opprettholde et godt og trivelig miljø med en åpen, konstruktiv kommunikasjon $(3,6)$.

Hvilke av områdene som vil kreve mest oppmerksomhet, vil variere fra prosjekt til prosjekt, og mellom de ulike fasene av et prosjekt. Prosjektleder er imidlertid den som skal knytte alle trådene sammen og kan derfor ikke tillate seg å ignorere noen av disse områdene (6).

\section{Hovedelementer}

Oppbygging og vektlegging av hovedelementer i prosjektledelse varierer og avhenger blant annet av hvilket fagområde litteraturen omhandler (1-6). Imidlertid går mange av elementene igjen, og på bakgrunn av dette samt med utgangspunkt i min egen erfaringsbakgrunn, vil jeg i det følgende fokusere på noen sentrale hovedelementer i prosjektledelse:

\section{Planlegging}

Prosjektarbeid skiller seg fra andre oppgaver ved at en i utgangspunktet starter på nytt hver gang (4). En god og grundig planleggingsfase, der både prosjektleder og sentrale prosjektmedarbeidere er trukket inn, er derfor et av suksesskriteriene for et vellykket prosjekt $(1,3,4)$. Grunnlaget for god prosjektledelse legges i planleggingsfasen, siden det er her vurderingene og rammene for styringsfaktorene legges, blant annet knyttet til mål, fremdrift og

\section{Grunnlaget for god prosjektledelse legges i planleggingsfasen.}

$ø$ konomi. I planleggingsfasen utarbeides prosjektbeskrivelsen som er den sammenfattende, skriftlige presentasjonen av prosjektet $(3,4)$. Prosjektbeskrivelsen skal være et organisk dokument, det vil si et dokument som skal benyttes i alle faser av prosjektet, både i presentasjon av prosjektet utad og ikke minst i bevisstgjøring og styring innad i prosjektet $(3,4)$. Erfaringsmessig kan det være hensiktsmessig å ha en kortversjon og en mer detaljert langversjon av prosjektbeskrivelsen. Kortversjonen benyttes i presentasjoner av prosjektet utad, mens langversjonen brukes innad i prosjektet og fungerer som prosjekterleders kart og «GPS» gjennom hele prosjektet. Det er prosjektleders ansvar å ha en utfyllende og god prosjektbeskrivelse som er detaljert nok til både å arbeide og styre prosjektet etter.

Teambygging

Prosjektledelse defineres ofte som «å oppnå mål gjennom andre»
(2 s. 188), noe som tydeliggjør at et godt prosjektresultat avhenger av samarbeid og teamarbeid (2). I all prosjektlitteratur legges det vekt på prosjektets oppstartsfase og teambygging (1-6). Team defineres som «en gruppe mennesker som arbeider mot felles måloppnåelse», og teambygging er en fellesbetegnelse på de metodene som prosjektledelsen benytter for å utvikle gode relasjoner, samhandling og lagfølelse mellom medarbeiderne (2). Litteraturen henviser til ulike måter å bygge team på; alt fra «kick off»-seminarer (4), teambyggingssykluser (2) til prosjektseminar (3). Uansett metode, hensikten er å skape entusiasme for oppgaven, bli kjent, få informasjon om bakgrunnen for prosjektet, skape en felles forståelse for oppgaven og mål for prosjektet (2-4). Erfaringsmessig kan det være lurt både å bli enig om forpliktende atferdsregler (3), for eksempel nedfelt i en gruppekontrakt, samt avklare roller og ansvarsforhold, for eksempel gjennom såkalte ansvarskart (4). For å utvikle teamfølelsen, er det viktig at man oppnår resultater raskt, og at milepælene derfor er nærliggende og resultatbestemte (3). Det er også viktig at teamet ikke er for stort (mindre enn ti personer), bruker tid sammen og at positive tilbakemeldinger vektlegges (2).

\section{Kommunikasjon}

Teamarbeid og kommunikasjon hører sammen. Kommunikasjon i prosjekter vil si å styre informasjonsflyten på alle nivå (4). Dette er kanskje prosjektets mest utfordrende oppgave, men den oppgaven som oftest er minst planlagt (2). I kommunikasjonsprosessen er mange mennesker involvert, den foregår på ulike nivå og på ulike måter $(3,4)$.

I prosjekter må en kommunisere med alle som blir berørt, noe blant annet «prosjektlederkompasset» synliggjør $(3,4,6)$. Det kan derfor være nyttig å gjennomgå områdene for å få et bilde av hvem og hvor mange kommunikasjonen i prosjektet omfatter (1). Dette antallet kommer ofte som en stor overraskelse for mange!

For å sikre god kommunikasjon, anbefales det å lage en kommunikasjonsplan (4). Kommunikasjonsplanen skal sikre en planlagt kommunikasjon som tydeliggjør hvem mottaker er, hvilken informasjon de skal ha, hvor ofte og hvem som har ansvar (4). Gjennom kommunikasjonsplanen sikres planlegging og styring av kommunikasjonen slik at ansvar tydeliggjøres og informasjon kommer på rett tid.

Møter er også et viktig kommunikasjonsmiddel i prosjekter. Det er derfor hensiktsmessig at en møtestruktur fastlegges tidlig for å sørge for nødvendig kommunikasjon og koordinering av informasjon (3). Alle prosjektmøter bør ha en dagsorden, styres og resultere i et referat. Referatene utgjør viktig dokumentasjon i prosjektet, og er ofte et godt hjelpemiddel når prosjektrapporten skal skrives.

Målrettet ledelse og oppfølging

Betydningen av prosjektets planleggingsfaser der blant annet pro-

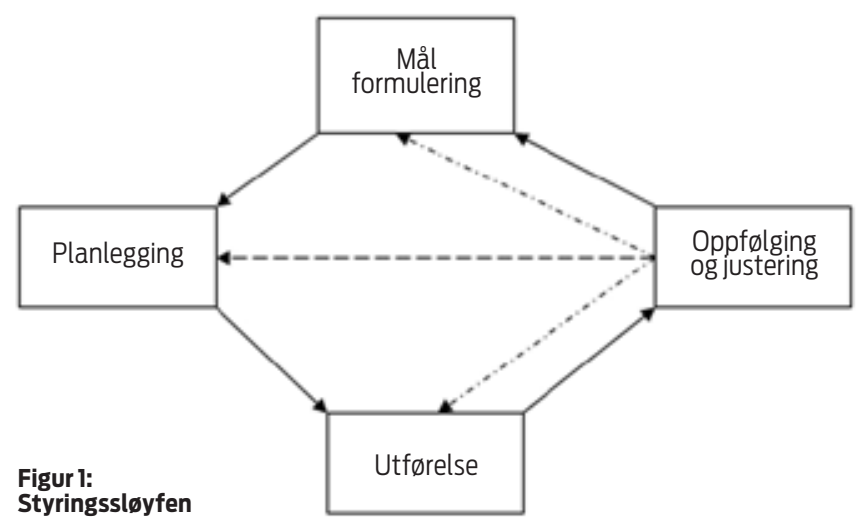


